\title{
APPLICATION OF DZIKIR TAHMID RELAXATION THERAPY TO REDUCE BLOOD SUGAR LEVEL AMONG PATIENTS WITH DIABETES MELLITUS IN KUDUS, CENTRAL JAVA
}

\author{
Sri Karyati, Sukarmin, Jenni Suciyanti Sarbini \\ Program in Nursing, School of Health Sciences Muhammadiyah Kudus
}

\begin{abstract}
Background: The literature suggests beliefs and religious practices are associated with: improved physical and mental health outcomes; having a beneficial effect on immune function; welfare; higher levels of satisfaction with life; hope; optimism; lower rates of anxiety and depression. This study aimed to determine the effect of dzikir tahmid relaxation therapy on the reduction of blood sugar level among patients with diabetes mellitus in Kudus, Central Java.

Subjects and Method: This study was a quasi-experiment (non-randomized) before and after with control group design conducted in Kudus, Central Java. A sample of 32 patients with type 2 of DM was selected for this study and allocated into 2 groups: 16 patients in the dzikir tahmid relaxation group and 16 patients in the control group. The dependent variable was blood sugar level. The independent variable was dzikir tahmid relaxation therapy. The data of blood sugar level was measured by blood glucose meter. The other data were collected by questionnaire. The data were analyzed by t-test.

Results: The reduction in blood sugar level in the dzikir tahmid relaxation therapy group was greater than the control group $(\mathrm{p}=0.021)$.

Conclusion: Dzikir tahmid relaxation therapy is effective to help reduce blood sugar level among patients with type 2 diabetes mellitus.
\end{abstract}

Keywords: diabetes mellitus, blood sugar level, dzikir tahmid, relaxation therapy

\section{Correspondence:}

Sri Karyati. Program in Nursing, School of Health Sciences Muhammadiyah Kudus, Central Java. Email: srikaryati@stikesmuhkudus.ac.id.

Mobile: 085555500000.

The 4th International Conference on Public Health

Best Western Premier Hotel, Solo, Indonesia, August 29-30, 2018 | 293 https://doi.org/10.26911/theicph.2018.05.07 